\title{
Üniversite Öğrencilerinin Yaşam Doyumunun Ölçülmesi
}

\author{
Irmak ARSLAN* ${ }^{*}$ Hakan BEKTAŞ**
}

$\ddot{O} \mathbf{z}$

Amaç: Bu çalışmada, İstanbul'da öğrenimini sürdürmekte olan Sağlık Bilimleri Fakültesi öğrencilerinin yaşam doyumunun ölçülmesi amaçlanmıştır.

Yöntem: Çalışmanın evrenini İstanbul'daki devlet ve vakıf yükseköğretim kurumlarının Sağllk Bilimleri Fakültesi’ne kayıtlı öğrenciler oluşturmuştur. İnternet tabanlı anket tekniği ile 10-20 Haziran 2019 tarihleri arasında veri toplanmıştır. Çalışmanın örnek büyüklüğü 182 öğrencidir. Çalışmada veri toplama aracı olarak kişisel bilgi formu ve Yaşam Doyum Ölçeği (The Satisfaction with Life Scale (SWLS)) kullanılmıştır. Çalışma kapsamında SWLS için geçerlilik ve güvenilirlik çalışması yapılmış, ardından hipotez testleri, korelasyon ve regresyon analizi uygulanmıştır.

Bulgular: Çalışmada SWLS ile toplanan veri kümesinin geçerli ve güvenilir olduğu saptanmıştır. Dolayısıyla yaşam doyumu skoru hesaplanmıştır. Uygulanan Mann-Whitney U testi neticesinde; yükseköğretim kurumu türüne göre yaşam doyumu açısından fark olduğu sonucuna varılmıştır. Bunun yanı sıra hesaplanan korelasyon katsayısıyla yaşam doyumu ve mutluluk arasında aynı yönlü orta kuvvetli ilişki olduğu bulunmuştur.

Sonuç: Çalışma sonucunda, vakıf yükseköğretim kurumlarına kayıtlı öğrencilerin devlet yükseköğretim kurumlarına kayıtlı öğrencilere kıyasla yaşam doyumu düzeyinin daha yüksek olduğu bulunmuştur. Bu doğrultuda, üniversitelerin öğrencilerin yaşam doyumunu arttırma açısından önemli bir rol oynadı̆̆ı düşünülmektedir. Kurumların bu sorumluluk doğrultusunda öğrencileri desteklemesi önerilmektedir. Ayrıca gelecek çalışmalarda bu ilişkiye aracı etki etmesi olası çeşitli faktörlerin (örn. gelir düzeyi) incelenmesi önerilmektedir.

Anahtar Sözcükler: Yaşam doyumu, mutluluk, yükseköğretim.

\footnotetext{
Özgün Araştırma Makalesi (Original Research Article)

Geliş / Received: 05.07.2019 \& Kabul / Accepted: 24.07.2019

* Doktora Öğrencisi, İstanbul Sabahattin Zaim Üniversitesi, Sosyal Bilimler Enstitüsü, Sosyal Hizmet Programı, İstanbul, Türkiye, E-posta: irmak.arslan@hotmail.com

ORCID ID https://orcid.org/o000-0001-5427-4355

** Dr. Öğr. Üyesi, İstanbul Ǘniversitesi, İktisat Fakültesi, Ekonometri Bölümü, İstanbul, Türkiye,

E-posta: hbektas@istanbul.edu.tr ORCID ID https://orcid.org/o0oo-0002-7856-2674
} 


\title{
Measuring Life Satisfaction of University Students
}

\begin{abstract}
Aim: In this study, it was aimed to measure life satisfaction of university students of the Faculty of Health Sciences who have been studying in Istanbul.

Method: The population of the study consists of students registered to Health Sciences Faculties of public and foundation higher education institutions. The data was collected between the dates of 10th to 2oth of June 2019 via internet-based survey technique. The sample size of the study is 182 students. Personal information form and Satisfaction with Life Scale (SWLS) were used for data collection. The validity and reliability study of SWLS, followed by hypothesis testing, correlation, and regression analysis were realized within the scope of the study.

Findings: It was found that the data set collected by SWLS was valid and reliable. Thus, life satisfaction scores were calculated. It was concluded that there was a difference in life satisfaction according to the type of higher education institute as a result of Mann-Whitney $U$ test applied. Also, a moderate relationship was found between life satisfaction and happiness in the same direction via calculated correlation coefficient.
\end{abstract}

Conclusion: As a result of the study, it was concluded that the life satisfaction of students registered to a foundation university was higher compared to students from a public university. Accordingly, it is presumed that the universities have an important role with respect to increasing life satisfaction of students. The institutes are suggested to support the students in line with this responsibility. Moreover, it is suggested for future studies to evaluate some factors (e.g,, income) for the possible mediating effect to this relationship.

Keywords: Life satisfaction, happiness, higher education.

\section{Giriş}

Günümüz insanının hızla akıp geçen yüksek tempolu bir hayata uyum sağlaması beklenmektedir. Bu açıdan bakıldığında gençlerin de, özellikle üniversite döneminde karşı karşıya geldikleri birçok problem, vermeleri gereken önemli kararlar ve onları bekleyen bir mücadelenin sürmekte olduğu görülmektedir. Kendilerini, nasıl bir kariyer planı çizecekleri, yaşamlarını nerede sürdürecekleri, ailelerinin beklentilerini karşılayıp karşlayamayacakları gibi soruları cevaplamakla yükümlü hissederler. Söz konusu belirsizlikler ve güçlüklerle ilişkili olarak üniversite öğrencilerinin strese bağlı çeşitli 
psikolojik sorunlar yaşayabildikleri, öznel iyilik hallerinin olumsuz etkilendiği bilinmektedir ${ }^{1}$.

Pozitif psikoloji; semptomlara ve olumsuzluklara odaklanmak yerine, kişinin olumlu yanlarını geliştirmeye ve zenginleştirmeye yönelik bir perspektif sunmaktadır. $\mathrm{Bu}$ bağlamda üniversite öğrencilerinin psikolojik sorunlarının yanı sıra; öznel iyilik haline yönelik çalışmalar, koruyucu ve önleyici müdahaleler önem kazanmıştır. Teorik zeminde araştırmalar, öznel iyiliğin sağlanması için hangi ihtiyaçların karşılanması gerektiği noktasından yola çıkmıştır. Sonrasında, öznel iyilik halinin bağlı olduğu faktörlerin hangi kaynaklara göre şekillendiği önem kazanmıştır. Dış etkenler, olaylar gibi faktörlerin düşük düzeyde etkileri tespit edilirken, kişinin kendisiyle ilgili faktörler (kişisel yargıları, hayat hedefleri, vb.) mercek altına alınmaya başlamıştır².

Diener, öznel iyilik halinin üç boyutundan söz etmektedir: Olumlu-olumsuz duygulanım, kişisel yargı ve yaşam doyumu ${ }^{3}$. Olumlu-olumsuz duygulanım neşe, eğlence, öfke, acı gibi duygusal boyutu temsil ederken, yaşam doyumu iyilik halinin bilişsel boyutunu temsil etmektedir ${ }^{4}$. Üniversite öğrencilerinin öznel iyilik haline katkıda bulunulması, bu boyutlar açısından güçlendirilmeleri ve desteklenmeleriyle mümkün gözükmektedir.

Dolayısıyla yaşam doyumunun anlaşılması ve çeşitli faktörlerle etkileşiminin incelenmesi gerekmektedir. Yaşam doyumunun zaman zaman yaşam kalitesi gibi kavramlarla eş anlamlı olarak kullanılmasına karşın, esasında yaşam kalitesi öznel ve nesnel kriterlere dayanırken, yaşam doyumunda öznel değerlendirme esas alınmaktadır5. Veenhoven, yaşam doyumunun tam olarak "zihinsel bir durum” olarak ele alınması gerektiğini ifade etmektedir ${ }^{6}$. Bu ifade, yaşam doyumunun öznelliğini yansitmaktadır.

Alanyazına bakıldığında, yaşam doyumu kavramına dair pek çok araştırma yapılmış olup kavram halen popülerliğini sürdürmektedir. Dünyada ve Türkiye'de üniversite öğrencilerinde yaşam doyumunu ele alan çalışmalar, yaşam doyumunu etkileyen çeşitli değişkenleri tespit etmeyi hedeflemektedir. Ele alınan bu değişkenlerden bazıları benlik saygısı $^{7}$, kişilik özellikleri 8 ve ebeveyn tutumlarıdır ${ }^{9}$. Çalışmalarda yaşam doyumu kavramının tanımı çeşitlilik göstermekle birlikte, genel olarak kişinin hayatını olumlu değerlendirme derecesi olarak ele alınmaktadır ${ }^{10}$. Başka bir deyişle, kişinin hayatının gidişatından ne derece memnun olduğu, yaşam doyumudur ${ }^{6}$. Öte yandan gençlerin 
yaşam doyumunun bağlı olduğu faktörlerin de çeşitlilik gösterdiği bilinmektedir ${ }^{11}$. Ayrıca insanların yaş aldıkça yaşam doyumlarını etkileyen faktörlerin zaman içinde değişiklik gösterdiğini öne süren çalışmalar da mevcuttur ${ }^{12}$.

Yapılan bir araştırmada, üniversite öğrencilerinin gelir düzeyleri düştükçe yaşam doyumlarının da düştüğü, ayrıca ebeveyn eğitim seviyeleri düşük olanların daha yüksek yaşam doyumu düzeylerine sahip olduğu tespit edilmiştir ${ }^{11}$. Bir başka araştırma üniversite öğrencilerinin yaşam doyumlarını; umutsuzluk ve kaygı düzeylerinin, eğitim doyumunun, ruh sağlı̆̆ı değerlendirmelerinin ve iş beklentilerinin yordadığını bulmuştur ${ }^{13}$. Farklı bir araştırmada, üniversite öğrencilerinde algılanan sosyoekonomik düzeyle yaşam doyumu arasında pozitif yönde anlamlı bir ilişki saptanmıştır ${ }^{14}$. Çivitci, üniversite öğrencileriyle yaptığı çalışmada yaşam doyumu yüksek olan öğrencilerin başarı ihtiyacının daha fazla olduğunu, yaşam doyumu yüksek kadın öğrencilerin başatlık ihtiyacının, yaşam doyumu düşük kadın öğrencilere göre daha fazla olduğunu tespit etmiştir¹5. Aynı araştırmada yaşam doyumu düşük erkek öğrencilerin özerklik ihtiyacının, yaşam doyumu yüksek olan erkek öğrencilere göre daha fazla olduğu görülmüştür. Bir diğer araştırmada ise yaş, cinsiyet ve fakülte hakkında ön bilgi sahibi olmanın yaşam doyumuyla anlamlı düzeyde ilişkili olduğu sonucuna varılmıştır ${ }^{1}$. Aynı araştırmada kadınların erkeklerden, yeni öğrencilerin (18-19 yaş) eskilerden (22-23 yaş) daha yüksek yaşam doyumuna sahip oldukları gözlenmiştir. Araştırmacılar bu sonucu mezuniyetin yaklaşması ve toplumsal cinsiyet rolleri açısından ele almıştır. Söz konusu fark; büyük yaş grubu ve erkek öğrencilerin gelecek kaygısı, ekonomik sorumluluklar gibi sebeplerle yaşam doyumlarının olumsuz etkileniyor olabileceği şeklinde yorumlanmıştır.

Öte yandan demografik özellikler ve yaşam doyumu arasında anlamlı ilişkiler bulunmayan çalışmalar da mevcuttur. Yapılan bir çalışmada farklı bölümlerde okuyan üniversite öğrencilerinin demografik özelliklerinin yaşam doyumu açısından anlamlı bir etkiye sahip olmadığı sonucuna varılmıştır ${ }^{16}$. Farklı bir çalışma, cinsiyet ve not ortalamasının gençlerin yaşam doyumuna etki etmediğini tespit etmiştir ${ }^{17}$. Yine benzer bir çalışmada, üniversite öğrencilerinde ebeveynlerin medeni durumu, en uzun süre yaşadığı yer ve öğretim türünün yaşam doyumuna herhangi bir etkisi olmadığı bulunmuştur ${ }^{18}$. Aynı çalışmada, öğrencilerin okudukları bölüm, ebeveyn tutumları ve duygusal zekânın yaşam doyumuyla ilişkili olduğu da varılan sonuçlar arasındadır. 
Özetle, bu alanda yapılan çalışmalarda genel olarak gençlerin yaşam doyumları ve demografik özellikleri arasında ilişkiler bulunduğu görülmektedir. Bu çalışmanın amacı, Sağlık Bilimleri Fakültesi'ne kayıtlı öğrencilerin yaşam doyumlarının incelenmesidir. Bu sayede gençlerin yaşam doyumlarını arttırmaya yönelik yapılacak uygulamalara ve alanyazına katkıda bulunulması beklenmektedir.

\section{Gereç ve Yöntem}

$\mathrm{Bu}$ çalışmada nicel araştırma yöntemlerinden tarama deseni kullanılmış ve bu kapsamda kesitsel çalışma yapılmıştır.

Çalışmanın evrenini İstanbul'daki devlet ve vakıf yükseköğretim kurumlarının Sağlık Bilimleri Fakültesine kayıtlı öğrenciler oluşturmuştur. Veri toplama aşamasında, elektronik anket türlerinden biri olan internet tabanlı anket tekniği kullanılmış; bu aşamada "Google formlar" üzerinden soru formu oluşturulmuştur. Soru formunun bulunduğu internet sitesi, 10-20 Haziran 2019 tarihleri arasında aktif tutulmuş ve çalışmaya gönüllülük esasına göre 208 öğrenci katılmıştır. Çalışma kapsamında hazırlanmış soru formuna katılımcıların dikkatini ölçmek amacıyla kontrol sorusu eklenmiştir. Toplanan veri kümesi incelendiğinde, kontrol sorusuna verilen yanttlardan hareketle 16 gözlem analiz dışında bırakılmıştır. Dolayısıyla örnek büyüklüğü 192 öğrenci olmuştur. Bilindiği üzere; veri kümesi genellikle uç değerler içerir. Uç değerlerin varlı̆̆ istatistiksel analizlerin sonuçlarını olumsuz yönde etkilemektedir. Dolayısıyla uç değerlerin ve anormal yanıt kalıplarının saptanması önem arz etmektedir. Açıklayıcı ve doğrulayıcı faktör analizi uygulanan bu çalışmada bahsedilen sebeple faktör modeli dikkate alınmış ve ileri arama algoritması kullanılarak uç değerler tespit edilmiştir. Bu aşamada faktör analizi modelleri için uç gözlemlerin saptanmasında metotlar sunan R programındaki "faoutlier" ${ }^{19}$ paketi kullanılmıştır. Bu bağlamda sıra dışı ve uç olarak tanımlanan 10 gözlem tespit edilmiş; söz konusu gözlemler silinmiş ve çalışmanın örnek büyüklüğü 182 öğrenci olmuştur. Bu öğrencilerin cinsiyet ve yaş değişkenlerine göre frekans dağılımı Tablo 1'de sunulmuştur. 
Tablo 1: Katılımcıların demografik özelliklerinin frekans dağglımı

\begin{tabular}{|c|c|c|c|}
\hline Değişken & Değişken Düzeyleri & Frekans & \% Frekans \\
\hline \multirow{2}{*}{ Cinsiyet } & Kadın & 159 & 87.4 \\
\cline { 2 - 4 } & Erkek & 23 & 12.6 \\
\hline \multirow{5}{*}{ Yaş } & 18 & 7 & 3.9 \\
\cline { 2 - 4 } & 19 & 20 & 11.0 \\
\cline { 2 - 4 } & 20 & 36 & 19.8 \\
\cline { 2 - 4 } & 21 & 51 & 28.0 \\
\cline { 2 - 4 } & 22 & 37 & 20.3 \\
\hline & 23 & 23 & 12.6 \\
\hline
\end{tabular}

Tablo 1 incelendiğinde; çalışmanın örnekleminin 159'u kadın (\%87.4) ve 23'ü erkek (\%12.6) olmak üzere toplam 182 öğrenciden meydana geldiği görülmektedir. $\mathrm{Bu}$ öğrencilerin \%68.1’inin yaşı 20 ile 22 yaş aralığındadır. Ayrıca bu katılımcıların kayıtlı oldukları yükseköğretim kurumunun türü, devam etmekte oldukları sınıf ve ağırlıklı genel not ortalaması (AGNO) değişkenlerine ait frekans dağılımı da Tablo 2'de verilmiştir.

Tablo 2: Katılımcıların öğrenim görmekte olduğu yükseköğretim kurumunun türü, sınıfı ve AGNO’larına ilişkin ilişkin frekans dağılımı

\begin{tabular}{|c|c|c|c|}
\hline Değişken & Değişken Düzeyleri & Frekans & \% Frekans \\
\hline \multirow{3}{*}{ Tür } & Devlet & 133 & 73.1 \\
\cline { 2 - 4 } & Vakıf & 49 & 26.9 \\
\hline \multirow{4}{*}{ Sinıf } & Birinci & 11 & 6.0 \\
\cline { 2 - 4 } & İkinci & 39 & 21.4 \\
\cline { 2 - 4 } & Üçüncü & 37 & 20.3 \\
\cline { 2 - 4 } & Dördüncü & 95 & 52.3 \\
\hline \multirow{4}{*}{ AGNO } & 2.49 ve altı & 22 & 12.1 \\
\cline { 2 - 4 } & $2.50-2.99$ & 68 & 37.4 \\
\cline { 2 - 4 } & $3.00-3.49$ & 69 & 37.9 \\
\cline { 2 - 4 } & 3.50 ve üzeri & 23 & 12.6 \\
\hline
\end{tabular}


Tablo 2 incelendiğinde; katılımcıların \%73.1'inin devlet yükseköğretim kurumlarına kayıtlı olduğu, \%52.3'ünün dördüncü sınıf öğrencisi olduğu ve \%75.3’ünün AGNO’sunun 2.50 ile 3.49 arasında yer aldığı görülmektedir.

Çalışmada veri toplama aracı olarak kişisel bilgi formu ve yaşam doyum ölçeği kullanılmıştır.

Kişisel Bilgi Formu: Katılımcıların demografik özelliklerini ortaya koymak amacıyla yöneltilen yaş ve cinsiyet sorularının yanı sıra devam edilmekte olan sınıf, kayıtlı olunan üniversitenin türü ve ağırlıklı genel not ortalaması (AGNO) sorularından oluşmaktadır.

Yaşam Doyum Ölçeği (The Satisfaction with Life Scale - SWLS): Diener ve diğerleri tarafından geliştirilmiş olup; 5 madde ve tek boyuttan meydana gelmektedir3. Tek boyutlu ölçekte bulunan maddelerin yanıt düzeyleri ise "1 - hiç katılmıyorum” ile “7 - kesinlikle katılıyorum” arasında yedi dereceli likert tipi olarak tasarlanmıştır. Bu ölçekte yer alan tüm maddeler olumlu ifadelerden oluşmaktadır ve yüksek puanlar, yüksek doyum seviyelerini göstermektedir. Diener ve diğerleri tarafından yapılan çalışma kapsamında geçerlilik ve güvenilirlik analizi gerçekleştirilmiştir. Bulgular, ölçeğin istenilen psikometrik özelliklere sahip olduğunu göstermiştir3. Bu ölçekteki maddelerin Türkçeye çevirisi ve ölçeğin yüzeysel geçerlilik çalışması, Köker tarafından gerçekleştirilmiştir. Bunun yanı sıra 17 ile 21 yaş arasındaki ergenler üzerine gerçekleştirilen bu çalışmada test-tekrar test yöntemiyle güvenilirlik analizi de yapılmıştır. Dolayısıyla ölçme aracının geçerli ve güvenilir olduğu sonucuna varılmıştır ${ }^{20}$.

Daha önce ifade edildiği üzere; bu çalışmada Sağlık Bilimleri Fakültesi öğrencilerinin yaşam doyumu ölçülmüştür. Dolayısıyla SWLS ile toplanan veri kümesinin geçerlilik ve güvenilirlik özelliklerinin araştırılması amacıyla; açıklayıcı faktör analizi (AFA) uygulanmıştır. Ardından güvenilirlik analizi gerçekleştirilmiştir. Elde edilen bulgular neticesinde, SWLS ölçeğinin istenilen psikometrik özelliklere sahip olduğu sonucuna varılmıştır. Takip eden aşamada ise, hipotez testleri, korelasyon ve regresyon analizleri uygulanmıştır. 
Çalışmada Urbano Lorenzo-Seva ve Pere Joan Ferrando tarafından geliştirilmiş olan FACTOR programı, istatistiksel hesaplama ve grafik çizimine imkân veren ücretsiz bir yazılım olan R ve SPSS kullanılarak veri analizi gerçekleştirilmiştir.

\section{Bulgular}

Çalışma kapsamında toplanan veri kümesi incelenerek; tutarsız ve uç gözlemler silinmiştir. Böylelikle çalışmanın örnek büyüklüğü 182 öğrenci olarak belirlenmiştir. Hatırlanacağı üzere; çalışmada SWLS ile veri toplanmıştır. Bu ölçme aracı için toplanan veri kümesinin geçerlilik ve güvenilirlik özelliklerini incelemek amacıyla öncelikle AFA uygulanmıştır.

Veri çözümlemesinde kullanılan çok değişkenli istatistiksel yöntemlerden biri olan AFA, veri kümesinin ardında yatan gizil yapının keşfedilmesini amaçlamaktadır. Dolayısıyla SWLS ile toplanan veri kümesinin ardındaki yapının ortaya çıkarılması ve böylelikle orijinal faktör yapısıyla bu çalışmadaki yapının kıyaslanabilmesi için AFA uygulanmıştır. Çünkü söz konusu faktör yapılarının aynı olması durumunda, geçerlilik özelliğinin sağlandığı söylenebilecektir. Bu aşamada öncelikle gözlenen değişkenler arasındaki korelasyon matrisinin faktörlenebilirliği araştırılmıştır. Bu kapsamda Kaiser-Meyer-Olkin (KMO) örneklem yeterlilik ölçütünün değeri ve Bartlett küresellik testi bulguları dikkate alınmıştır. Bartlett küresellik testi $\left(\chi^{2}=360, d f=10, p=0,00\right)$ ve KMO ölçütü (0.861) korelasyon matrisinin AFA için uygun olduğunu göstermiştir. Takip eden aşamada, ağırlıklandırılmamış en küçük kareler metodu ile faktör modeli tahmin edilmiştir. Uygun faktör sayısının belirlenmesinde ise Kaiser-Guttman kuralı, Hull yöntemi ve yorumlanabilirlik kriteri dikkate alınmış olup; faktör sayısı bir olarak saptanmıştır. Tablo 3’te maddelere ait tanımlayıcı istatistikler ve faktör yükleri bulunmaktadır. 
Tablo 3: Açıklayıcı faktör analizi sonucu

\begin{tabular}{|l|l|l|l|}
\hline Maddeler & Ortalama & $\begin{array}{l}\text { Standart } \\
\text { Sapma }\end{array}$ & $\begin{array}{l}\text { Faktör } \\
\text { Yükü }\end{array}$ \\
\hline Yaşamımdan memnunum (YD3) & 4.725 & 1.472 & 0.795 \\
\hline Yaşamım birçok yönüyle ideallerime yakın (YD1) & 4.066 & 1.511 & 0.773 \\
\hline Yaşam koşullarım mükemmel (YD2) & 3.929 & 1.434 & 0.724 \\
\hline $\begin{array}{l}\text { Şimdiye kadar yaşamda istediğim önemli şeyleri } \\
\text { elde ettim (YD4) }\end{array}$ & 4.346 & 1.353 & 0.707 \\
\hline $\begin{array}{l}\text { Yeniden dünyaya gelseydim, yaşamımda hemen } \\
\text { hemen hiçbir şeyi değiştirmezdim (YD5) }\end{array}$ & 3.247 & 1.799 & 0.676 \\
\hline
\end{tabular}

Tablo 3 incelendiğinde; her bir madde için ortalama, standart sapma ve türetilen modeldeki faktör yükü görülmektedir. Hatırlanacağı üzere; katılımcılar yaşam doyum düzeylerini 1 ile 7 arasında yedi dereceli bir ölçekte belirtmiş ve bütün maddeler olumlu ifadelerden oluşmuştur. Dolayısıyla bu bağlamda, ortalama ve standart sapma değerlerinin değerlendirilmesi gerekmektedir. Bunun yanı sıra türetilen faktör modelinin açıklanan varyans oranı \%63.237 olarak hesaplanmıştır. Bu çalışmada AFA kullanılarak türetilen faktör modeli ile tek boyutlu olan SWLS yapılarının aynı olduğu saptanmıştır. Yani, geçerlilik özelliğinin sağlandığı görülmüş̧ür. Dolayısıyla ölçülmek istenilenin yani yaşam doyumunun isabetli olarak ölçüldüğü sonucuna varılmıştır.

AFA ile verinin doğası yansıtılmış ve takip eden aşamada güvenilirlik analizi gerçekleştirilmiştir. Bu kapsamda içsel tutarlılık güvenilirliği için Cronbach alfa katsayısı hesaplanmış ve Tablo 4’te sunulmuştur.

Tablo 4: Güvenilirlik analizi

\begin{tabular}{|c|c|c|c|c|}
\hline \multirow{2}{*}{ Faktör } & \multirow{2}{*}{ Madde Sayısı } & \multirow{2}{*}{ Cronbach Alfa } & \multicolumn{2}{|c|}{$\begin{array}{c}\text { Madde-Toplam Korelasyon } \\
\text { Değeri }\end{array}$} \\
\cline { 3 - 5 } & & & En Düşük & En Yüksek \\
\hline Yaşam Doyumu & 5 & 0.850 & 0.619 & 0.714 \\
\hline
\end{tabular}


Tablo 4 incelendiğinde; içsel tutarlılık güvenilirliği için hesaplanan Cronbach alfa katsayısının değeri 0.850'dir. Bu bulgu, toplanan veri kümesinin güvenilirlik özelliğine sahip olduğunu göstermektedir ${ }^{21}$. Ayrıca Tablo 4'te madde-toplam korelasyon değerlerine de yer verilmiştir. Elde edilen bulgular neticesinde; SWLS ile toplanan veri kümesinin geçerli ve güvenilir olduğu sonucuna varılmıştır. Dolayısıyla beş maddeden meydana gelen tek boyutlu SWLS ile toplanan veri kümesinden hareketle; araştırma amacı doğrultusunda hipotezler sınanmıştır. Bu aşamadan önce hipotez testlerinde kullanılmak üzere; faktör skoru hesaplanmıştır. Yanıtların toplanması yaklaşımı ile hesaplanan faktör skoru verisine ait tanımlayıcı istatistikler Tablo 5’te sunulmuştur.

Tablo 5: Faktör için tanımlayıcı istatistikler

\begin{tabular}{|c|c|c|c|c|}
\hline Faktör & En küçük değer & En büyük değer & Ortalama & Standart sapma \\
\hline Yaşam Doyumu & 5 & 33 & 20.313 & 6.012 \\
\hline
\end{tabular}

Hatırlanacağı üzere; AFA ile türetilen faktör modelinde 5 madde bulunmaktadır. $\mathrm{Bu}$ maddeler için katılımcıların yanıt düzeyleri 1 ile 7 arasında ölçeklendirilmiştir. Dolayısıyla bütün maddelere 1-hiç katılmıyorum yanıtını veren bir katılımcının faktör skoru 5’tir. Diğer yandan, bütün maddeleri 7-kesinlikle katılıyorum şeklinde puanlayan katılımcının faktör skoru ise 35’tir. Bu açıdan Tablo 5 incelendiğinde; seride en küçük değerin 5 ve en büyük değerin 33 olduğu görülmektedir. Faktör skorlarının ortalaması 20.313 ve standart sapması 6.012 olarak hesaplanmıştır. Bunun yanı sıra yaşam doyumu skorlarının medyanı 20.500 olduğunu belirtmek gerekmektedir. Yani, geleneksel yaklaşıma göre bu serinin simetrik olduğu söylenebilmektedir. Ayrıca hesaplanan değer, çalışmadaki katılımcıların yaşam doyumundan ne memnun ne memnun değil olduğu şeklinde yorumlanabilir. Çünkü yedi dereceli ölçeklendirmede kararsızlık durumu 4 ile temsil edilmiştir.

$\mathrm{Bu}$ çalışmada kişisel soru formundaki değişkenlerin yanıt kategorileri kullanılarak; değişken bazında kategoriler arasında yaşam doyumu açısından fark olup olmadığı sınanmıştır. $\mathrm{Bu}$ amaç doğrultusunda hipotez testleri kullanılmıştır. Bilindiği üzere hipotez testleri, parametrik ve parametrik olmayan testler olarak iki başlık altında ele alınmaktadır. Bu aşamada verinin ölçüm düzeyi, dağılımın şekli, örnek büyüklüğü, grupların eşlenik olup olmaması gibi hususlar dikkate alınarak uygun teste karar 
verilmektedir. Bu çalışma kapsamında öncelikle kadın ve erkek grupları arasında yaşam doyumu açısından istatistiksel olarak fark bulunup bulunmadığı sorusuna yanıt aranmıştır. Parametrik test varsayımları sağlanamadığından kitle dağılımı hakkında herhangi bir varsayım gerektirmeyen Mann-Whitney U testi kullanılmıştır. Bu testin temel hipotezi, iki kitlenin aynı dağılıma sahip olduğunu göstermektedir. Bu bağlamda grup ortancaların birbirine eşit olup olmadığını sınamaktadır. Dolayısıyla sıra numaraları üzerinden test gerçekleştirilmektedir ${ }^{22}$. Cinsiyete göre yaşam doyumu düzeyleri açısından fark olup olmadığını sınamak için uygulanan Mann-Whitney U testinin sonucu Tablo 6'da yer almaktadır.

Tablo 6: Cinsiyete göre yaşam doyumunun kıyaslanması

\begin{tabular}{|c|c|c|c|}
\hline Grup & Gözlem Sayısı & Sıra Ortalaması & $\begin{array}{c}\text { Test Ístatistiğinin Olasılık } \\
\text { Değeri }\end{array}$ \\
\hline Kadın & 159 & 93.130 & 0.273 \\
\hline Erkek & 23 & 80.260 & \\
\hline
\end{tabular}

Tablo 6 incelendiğinde; kadın ve erkek grupları arasında yaşam doyumu açısından 0,05 düzeyinde istatistiksel olarak fark bulunmadığg görülmektedir. Diğer bir ifadeyle, temel hipotez reddedilememiştir.

Katılımcıların kayıtlı oldukları yükseköğretim kurumunun türüne göre yaşam doyumunun kıyaslanması amacıyla yine Mann-Whitney U testi uygulanmış ve elde edilen bulgular Tablo 7’de sunulmuştur.

Tablo 7: Yükseköğretim kurumu türüne göre yaşam doyumunun kıyaslanması

\begin{tabular}{|c|c|c|c|}
\hline Grup & Gözlem Sayısı & $\begin{array}{c}\text { Sıra } \\
\text { Ortalaması }\end{array}$ & $\begin{array}{c}\text { Test Ístatistiğinin Olasılık } \\
\text { Değeri }\end{array}$ \\
\hline Devlet & 133 & 86.570 & 0.037 \\
\hline Vakıf & 49 & 104.880 & \\
\hline
\end{tabular}

Tablo 7 incelendiğinde; kayıtlı olunan yükseköğretim kurumu türüne göre yaşam doyumu açısından o.o5 düzeyinde istatistiksel olarak fark olduğu görülmektedir. Yani, 
temel hipotez reddedilememiştir. Bu çalışmada vakıf yükseköğretim kurumlarına kayıtlı öğrencilerin, devlet yükseköğretim kurumlarına kayıtlı öğrencilere kıyasla yaşam doyumunun daha yüksek olduğu saptanmıştır.

Çalışma kapsamında AGNO grupları arasında yaşam doyumu açısından fark olup olmadığı da sınanmıştır. AGNO değişkeninin dört yanıt kategorisi bulunduğundan ve verinin parametrik test varsayımlarını sağlamamasından dolayı ikiden fazla grubun kıyaslanması için Kruskal-Wallis sınaması kullanılmıştır. Bu test, Mann-Whitney U sınamasının genişletilmiş hali olup; temel hipotezi yine farksızlığı göstermektedir ${ }^{22}$. Dolayısıyla ikiden fazla kategorisi olan AGNO değişkenine göre yaşam doyumu açısından fark olup olmadığı Kruskal-Wallis testi ile sınanmış ve bulgular Tablo 8'de sunulmuştur.

Tablo 8: AGNO’ya göre yaşam doyumunun kıyaslanması

\begin{tabular}{|c|c|c|c|}
\hline Grup & $\begin{array}{c}\text { Gözlem } \\
\text { Sayısı }\end{array}$ & Sıra Ortalaması & $\begin{array}{c}\text { Test İstatistiğinin Olasılık } \\
\text { Değeri }\end{array}$ \\
\hline 2.49 ve altı & 22 & 82.480 & \multirow{2}{*}{0.828} \\
\hline $2.50-2.99$ & 68 & 91.150 & \\
\hline $3.00-3.49$ & 69 & 94.580 & \\
\hline 3.50 ve üzeri & 23 & 91.930 & \\
\hline
\end{tabular}

Tablo 8 incelendiğinde; AGNO grupları arasında yaşam doyumu açısından 0.05 düzeyinde istatistiksel olarak anlamlı fark bulunmadığı görülmektedir.

Devam etmekte olunan sınıfa göre yaşam doyumu açısından istatistiksel olarak fark bulunup bulunmadığı araştırılmış ve elde edilen bulgular Tablo 9'da sunulmuştur. 
Tablo 9: Sınıfa göre yaşam doyumunun kıyaslanması

\begin{tabular}{|c|c|c|c|}
\hline Grup & $\begin{array}{c}\text { Gözlem } \\
\text { Sayısı }\end{array}$ & Sıra Ortalaması & $\begin{array}{c}\text { Test Ístatistiğinin Olasılık } \\
\text { Değeri }\end{array}$ \\
\hline Birinci sınıf & 11 & 85.500 & \multirow{2}{*}{0.800} \\
\hline İkinci sınıf & 39 & 96.040 & \\
\hline Üçüncü sınıf & 37 & 85.280 & \\
\hline Dördüncü sınıf & 95 & 92.750 & \\
\hline
\end{tabular}

Tablo 9'a göre, devam etmekte olunan sınıf grupları arasında yaşam doyumu açısından o.05 düzeyinde istatistiksel olarak anlamlı fark saptanmamıştır.

Çalışma kapsamında katılımcılardan genel olarak mutluluk düzeylerini 1 ile 11 arasında puanlamaları da istenmiştir. Mutluluk değişkenine ait tanımlayıcı istatistikler Tablo 10'da yer almaktadır.

Tablo 10: Mutluluk değişkenine ait tanımlayıcı istatistikler

\begin{tabular}{|c|c|c|c|c|}
\hline Değişken & En küçük değer & En büyük değer & Ortalama & Standart sapma \\
\hline Mutluluk & 2 & 10 & 6.961 & 1.599 \\
\hline
\end{tabular}

Tablo 10 incelendiğinde; katılımcıların genel olarak algıladıkları mutluluk düzeyi 2 ile 10 aralığında değiştiği görülmektedir. Ayrıca bu değişkenin ortalaması 6.961 ve standart sapması 1.599 olarak hesaplanmıştır. Alanyazını incelendiğinde yaşam doyumu ve mutluluk değişkenleri arasında ilişki olduğu gözlenmiştir. Dolayısıyla yaşam doyumu ve mutluluk değişkenleri arasında doğrusal ilişkinin yönü ve derecesi araştırılmıştır. Hesaplanan korelasyon katsayısının değeri 0.648 olup; bu katsayı 0.05 düzeyinde istatistiksel olarak anlamlıdır. Bu değer, iki değişken arasında aynı yönlü ve orta kuvvetli ilişki olduğunu göstermiştir. Kuramsal çerçeve düşünüldüğünde mutluluğun yaşam doyumunun nedeni olduğu bilinmektedir. Bu aşamada regresyon analizi gerçekleştirilmiştir. Regresyon modelinin yorumlanmasına geçmeden önce modelin varsayımları sağlayıp sağlamadığı araştırılmıştır. İstatistiksel olarak anlamlı olan modelin, regresyon modelinin varsayımlarını yerine getirdiği de saptanmıştır. $\mathrm{Bu}$ 
model için hesaplanan belirginlik katsayısı ise 0.420 olarak hesaplanmıştır. Yani yaşam doyumunda meydana gelen değişimin \%42'si mutluluk değişkenindeki değişimler tarafından açıklanmaktadır. Tahmin edilen model Eşitlik 1.1'de yer almaktadır.

$$
\text { Yaşam Doyumu }=3.355+2.436 \text { Mutluluk }
$$

Eşitlik 1.1'e göre; mutluluk değişkeninde meydana gelen bir birimlik artış yaşam doyumunun ortalama 2.436 birim artmasına neden olmaktadır.

\section{Tartışma}

$\mathrm{Bu}$ çalışmada Diener ve diğerleri3 ${ }^{3}$ tarafından geliştirilmiş SWLS kullanılarak yaşam doyumu ölçülmüştür. Söz konusu ölçek, tek boyutlu olup; beş maddeden meydana gelmektedir. Toplanan veri kümesinden hareketle; geçerlilik ve güvenilirlik çalışması yapılmıştır. $\mathrm{Bu}$ aşamada öncelikle AFA uygulanmış ve ulaşlan bulgular neticesinde çalışmada türetilen faktör yapısının orijinal faktör yapısıyla aynı olduğu sonucuna varılmıştır. Böylelikle geçerlilik özelliğinin sağlandığı tespit edilmiştir. Takip eden aşamada içsel tutarlılık güvenilirliği için Cronbach alfa katsayısı hesaplanmış ve güvenilirlik özelliğinin de sağlandığı görülmüştür. Sonraki aşamada ise, türetilen faktör modelinden hareketle faktör skorları hesaplanmıştır, diğer bir ifadeyle yaşam doyumu değişkeni türetilmiştir. Dolayısıyla yaşam doyumu açısından cinsiyet, devam edilmekte olan sınıf, AGNO, kayıtlı olunan yükseköğretim kurumunun türü değişkenlerinin grupları dikkate alınarak parametrik olmayan hipotez testleri uygulanmıştır. Uygulanan Mann-Whitney U testi neticesinde, vakıf yükseköğretim kurumlarına kayıtlı öğrencilerin devlet yükseköğretim kurumlarına kayıtlı öğrencilere kıyasla yaşam doyumu düzeyinin daha yüksek olduğu saptanmıştır.

Elde edilen bu bulgu sonucunda, üniversitelerin öğrencilerin yaşam doyumunu arttırma açısından önemli bir rol oynadığı düşünülmektedir. Kurumların bu sorumluluk doğrultusunda öğrencileri desteklemesi önerilmektedir. Vakıf üniversitelerinin sunduğu kariyer danışmanlığı, burs imkânları, sosyal aktivitelerin çeşitliliği ve çokluğu gibi faktörlerin öğrencilerin yaşam kalitesini olumlu etkilemesi ihtimali dikkate alınmalıdır. Ayrıca gelecek çalışmalarda bu ilişkiye aracı etki etmesi olası çeşitli faktörlerin (örn. gelir düzeyi, iş beklentisi, kayıtlı olduğu bölüme uygunluk vb.) incelenmesi önerilmektedir. Öte yandan yaşam doyumuyla cinsiyet, devam 
edilmekte olan sınıf ve AGNO arasında anlamlı herhangi bir ilişkiye rastlanmamıştır. Alanyazına bakıldığında, benzer sonuçlara varan çalışmalar bulunmaktadır ${ }^{16-18,20}$.

Bunun yanı sıra mutluluk ile yaşam doyumu arasındaki doğrusal ilişkinin yönü ve derecesi araştırılmış ve korelasyon katsayısının değeri 0.648 olarak bulunmuştur. Dolayısıyla iki değişken arasında aynı yönlü ve orta kuvvetli ilişki olduğu sonucuna varılmıştır. Teorik çerçeve dikkate alındığında mutluluğun yaşam doyumunu açıkladığı bilinmektedir. Bundan dolayı bağımlı değişken yaşam doyumu olmak üzere regresyon analizi gerçekleştirilmiş ve mutluluk değişkeninde meydana gelen 1 birimlik artışın yaşam doyumunun ortalama 2.436 birim artmasına neden olduğu saptanmıştır.

Diener, gerçekleştirdiği gözden geçirme çalışmasında öznel iyilik hali kavramını mutluluk kavramıyla dönüşümlü olarak kullanmıştır². Yaşam doyumu, öznel iyilik halinin bir boyutu olarak değerlendirilmektedir ${ }^{3,4}$. Dolayısıyla mevcut çalışmada tespit edilen yaşam doyumu ve mutluluk ilişkisi, alanyazınla örtüşmektedir.

\section{Sonuç}

Mevcut çalışma, Sağlık Bilimleri Fakültesi öğrencilerinin yaşam doyumlarının vakıf veya devlet yükseköğretim kurumlarına kayıtlı olmalarına bağlı olarak değişiklik gösterdiğini bulmuştur. Bu farkın okul türünün doğrudan bir sonucu olabileceği gibi, çeşitli faktörlerin etkisi sonucu ortaya çıkmış olabileceği de düşünülmektedir. Öğrencilerin okudukları bölüme yönelik memnuniyeti, gelecek beklentileri, algıladıkları sosyal destek gibi çeşitli faktörlerin bu ilişkide aracı rolü olabileceği değerlendirilmelidir. Öte yandan, vakıf ve devlet yükseköğretim kurumları arasında yapısal farklılıkların araştırılması, eğer varsa tespit edilen farklılıklar açısından iyileştirmelere gidilmesi, öğrencilerin yaşam kalitesini arttırmada faydalı olacaktır. Çalışmanın bir diğer bulgusu, öğrencilerin yaşam doyumlarıyla mutlulukları arasındaki anlamlı ilişkidir. Öğrencilere sunulacak psikolojik danışmanlık, sosyal destek gibi mekanizmaların öğrencilerin mutluluk düzeylerini arttıracağı, dolayısıyla yaşam doyumlarına olumlu etkide bulunacağı düşünülmektedir.

Çalışmanın kısıtları olarak; örneklemin sadece İstanbul'daki Sağlık Bilimleri Fakültesi’ne kayıtlı öğrencilerinden oluşması ve örneklem büyüklüğünün 182 kişiyle sınırlı kalması gösterilmektedir. Dolayısıyla çalışmada elde edilen bulgular genelleştirilememektedir. Gelecek araştırmalarda daha geniş ve çeşitlilik gösteren bir 
örneklemle çalışılması faydalı olacaktır. Bu çalışma kapsamında Sağlık Bilimler Fakültesi öğrenci için SLWS’nin geçerlilik ve güvenilirlik özellikleri incelenmiş olup; SWLS'nin Türkçe versiyonunun istenilen psikometrik özelliklere sahip olduğu sonucuna ulaşılmıştır. Dolayısıyla SWLS kullanılarak Sağlık Bilimleri Fakültesi öğrencileri üzerine gerçekleştirilecek araştırmalarda AFA yerine doğrudan doğrulayıcı faktör analizi kullanılarak faktör yapısının onaylanması yeterli olacaktır.

\section{KAYNAKLAR}

1. Aldemir C, Gülcan Y. Student satisfaction in higher education: A Turkish case. Journal of Higher Education Management and Policy . 2004;16(2):109-122. doi: 10.1787/hemp-v16-art19-en.

2. Diener E, Suh EM, Lucas RE, Smith HL. Subjective well-being: Three decades of progress. Psychological Bulletin. 1999;125(2):272-302.

3. Diener ED, Emmons RA, Larsen RJ, Griffin S. The satisfaction with life scale. Journal of Personality Assessment. 1985;49(1):71-75. doi: 10.1207/s15327752jpa4901_13.

4. Diener E. Subjective well-being. Psychological Bulletin. 1984;95(3):542. doi: 10.1037/0033-2909.95.3.542.

5. Afşar ST. Çalışma Yaşam Kalitesinin Örgütsel Bağlılık Düzeyi Üzerindeki Etkisi: Devlet ve Vakıf Üniversitelerinde Çalışan Akademisyenler Üzerine Nicel Bir Araştırma. [doktora tezi]. Ankara, Türkiye: Hacettepe Üniversitesi, Sosyal Bilimler Enstitüsü; 2011.

6. Veenhoven R. The study of life satisfaction. In: Saris WE, Veenhoven R, Scherpenzeel AC, Bunting B. ed(s). A Comparative Study of Life Satisfaction with Life in Europe. Budapest: Eötvös University Press; 1996:11-49.

7. Çeçen AR. Üniversite öğrencilerinde yaşam doyumunu yordamada bireysel bütünlük (tutarlılık) duygusu, aile bütünlük duygusu ve benlik saygısı. Eğitimde Kuram ve Uygulama. 2008;4(1):19-30.

8. Çapan BE. Relationship among perfectionism, academic procrastination and life satisfaction of university students. Procedia-Social and Behavioral Sciences. 2010;5:1665-1671. doi: 1 0.1016/j.sbspro.2010.07.342. 
9. Deniz ME, Karakuş Ö, Traş Z, Eldeleklioğlu J, Özyeşil Z, Hamarta E. Parental attitude perceived by university students as predictors of subjective well-being and life satisfaction. Psychology. 2013;4(3):169-173. doi: 10.4236/psych.2013.43025.

10. Toker B. Life satisfaction among academicians: an empirical study on the universities. Procedia - Social and Behavioral Sciences. 2012;47:190-195. doi: 10.1016/j.sbspro.2012.06.637.

11. Bozgeyikli H, Işıklar A, Eroğlu SE. Demographic variables and levels of life satisfaction: The case of students enrolled in apprenticeship training. African Journal of Business Management. 2010;4(7):1336-1345.

https://academicjournals.org/journal/AJBM/article-full-text-pdf/768CFBC25993. Erişim tarihi 15 Haziran 2019.

12. Siedlecki KL, Tucker-Drob EM, Oishi S, Salthouse TA. Life satisfaction across adulthood: Different determinants at different ages? The Journal of Positive Psychology. 2008;3(3):153-164. doi: 10.1080/17439760701834602.

13. Gündoğar D, Gül SS, Uskun E, Demirci S, Keçeci D. Üniversite öğrencilerinde yaşam doyumunu yordayan etkenlerin incelenmesi. Klinik Psikiyatri. 2007;10(1):14-27.

14. Yıkılmaz M, Demir Güdül M. Üniversite öğrencilerinde yaşamda anlam, bilinçli farkındalık, algılanan sosyoekonomik düzey ve yaşam doyumu arasındaki ilişkiler. Ege Eğitim Dergisi. 2015;16(2):297-315.

15. Çivitci A. Üniversite öğrencilerinde genel yaşam doyumu ve psikolojik ihtiyaçlar arasındaki ilişkiler. Çukurova Üniversitesi Sosyal Bilimler Enstitüsü Dergisi. 2012;21(2):321-336.

16. Hırlak B, Taşlıyan M, Sezer B. İyimserlik ve yaşam doyumu arasındaki ilişki ve demografik özellikler bağlamında algı farklılıkları: Bir alan araştırması. Kahramanmaraş Sütçü İmam Üniversitesi İktisadi ve İdari Bilimler Fakültesi Dergisi. 2017;7(1):95-116.

17. Huebner ES, Drane W, Valois RF. Levels and demographic correlates of adolescent life satisfaction reports. School Psychology International. 2000;21(3):281292. doi: 10.1177/0143034300213005.

18. Bakan İ, Güler B. Duygusal zekânın, yaşam doyumu ve akademik başarıya etkileri ve demografik özellikler bağlamında algı farklılıkları. Karamanoğlu Mehmetbey Üniversitesi Sosyal ve Ekonomik Araştırmalar Dergisi. 2017;19(33):1-11. 
19. Chalmers, P. faoutlier: Influential case detection methods for factor analysis and structural equation models, https://cran.rproject.org/web/packages/faoutlier/index.html Yayımlanma tarihi Temmuz 2017. Erişim tarihi o1 Temmuz 2019

20. Köker, S. Normal ve Sorunlu Ergenlerin Yaşam Doyumu Düzeyinin Karşılaştırılması. [yüksek lisans tezi]. Ankara, Türkiye; Eğitimde Psikolojik Hizmetler, Ankara Üniversitesi Sosyal Bilimler Enstitüsü; 1991.

21. Nunnally JC, Bernstein IH. Psychometric Theory. Third Edition. USA: McGrawHill Inc; 1994.

22. Sheskin, DJ. Handbook of Parametric and Nonparametric Statistical Procedures. Third Edition. Boca Raton, Florida: Chapman\&Hall / CRC Press; 2004. 